\title{
STUDY OF THE PURIFICATION PERFORMANCE OF THE NATURAL LAGUNATING TECHNIQUE OF THE PURIFICATION STATION OF THE CITY OF OUTAT EL HAJ - MOROCCO
}

\author{
H. Ech-chafay ${ }^{1 *}$, M.Najy ${ }^{1}$, F. Z. Talbi ${ }^{2}$, A. El Ghazouany ${ }^{1}$, M. Lachhab ${ }^{1}$, D. Belghyti ${ }^{1}$ \\ ${ }^{1}$ Laboratory of Agro-physiology, Biotechnology, Environment and Quality, Department of Biology University Ibn Tofail, Faculty of \\ Science Kenitra, Morocco \\ ${ }^{2}$ Laboratory Biotechnology and Preservation of Natural Resources Faculty of Sciences Dhar El Mahraz Sidi Mohamed Ben Abdellah \\ University, Fez, Morocco
}

KEY WORDS: Sewage Treatment Plant, Purification Performance, Physico-Chemistry, Outa El Haj, Morocco.

\begin{abstract}
:
The availability of land and the climatic conditions encouraged by the geographical situation of Morocco, have pushed this country to adopt since the 90 s natural leaning as being the technical solution most suited to the economic and climatic context, thus, many treatment stations wastewater has already been carried out. In order to assess the performance of the natural lagoon-type treatment plant in the town of Outat El Haj, we studied the physicochemical parameters of the raw and purified water from the plant. For this, we carried out a set of measurements such as: Temperature, $\mathrm{pH}$ and Electrical Conductivity (EC) (parameters on site), Biochemical Oxygen Demand (BOD5), Chemical Oxygen Demand (COD), Suspended Solids (TSS), Dissolved Oxygen, Hydrotimetric Titer (TH), Cl- Chloride, Organic Matter $(\mathrm{OM})$, Orthophosphates, and Nitrates, in order to examine the reliability of this purification process in the study area. The purification yields observed in the treatment plant vary from 23 to $94.6 \%$ as an abatement for BOD $_{5}$. This average yield varies between 22.3 and 89.8\% for COD, between 22.6 and $90.6 \%$ for OM, and between 9.2 and $65.5 \%$ for suspended matter (suspended matter). The purification performance is negative to very low in nitrogen and Orthophosphates. The results of the analyzes showed that the purification yields of the natural lagoon-type station, low, variable and remain dependent on the season.
\end{abstract}

\section{INTRODUCTION}

Protecting the environment has long since become a major economic and political issue. Among the priorities is the safeguarding of water resources. Water is necessary for life and human activity, but the demand for water is not uniform from one region of the globe to another and the availability of resources even less (JACQUET V). Demographic, economic and urban increases are at the origin of various sources of environmental pollution, especially in developing countries less concerned and less aware of health risks. Among these sources of pollution, the production of wastewater which is often discharged into the natural environment without prior treatment.

Currently, the actual total volume of wastewater discharged in Morocco is estimated at around 750 million $\mathrm{m}^{3} ; 48 \%$ of this water is discharged into rivers and the natural environment; the rest is thrown back into the sea without any prior treatment. The polluting load of wastewater is estimated at around 131,715 tonnes of organic load, 42,131 tonnes of nitrogen and 6,230 tonnes of phosphorus (Mandi, 2013).

Indeed, Morocco has more than 100 wastewater treatment plants, of which $77 \%$ are natural lagoons including that of the city of Outat El Haj, 15\% use other techniques (aerated lagoons, bacterial filters ... ), and $8 \%$ of activated sludge (Makhokh, 2011). The WWTP receives almost all of the wastewater from the city of Outat El Haj.

\section{MATERIALS AND METHOD}

\subsection{Study site}

The city of OUTAT EL HAJ is located in the region of Fès Meknes, province of Boulmane, is approximately $250 \mathrm{~km}$ north- east of Fez and $130 \mathrm{~km}$ south-west of the city of Guércif on the RN $15 .^{1}$

Its population was 18,000 inhabitants in 2012. Its main industries are slaughterhouses and olive mills. It has a separate sewerage network, which flows into a water treatment plant (STEP) by lagoon located about $360 \mathrm{ml}$ from the outskirts of the city (ONEP, 2012).

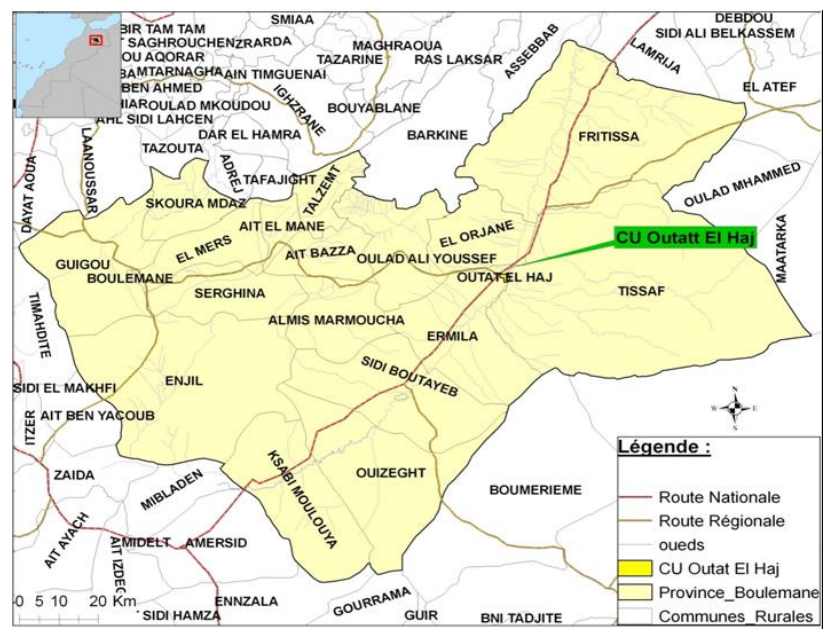

Figure 1. Location of the study area and sampling sites

\subsection{Description of the WWTP}

The wastewater treatment plant in the town of Outat El Haj is intended for collective sanitation of the town's wastewater. It is located $360 \mathrm{~m}$ from the outskirts of the city three kilometers 
North-East of the city, these GPS coordinates are $\mathrm{N} 32^{\circ} 1$ '57.099' 'W 4 '' 14.912',

The station is sized to receive a nominal flow of $880 \mathrm{~m} 3 / \mathrm{d}$ by the year 2020, with a nominal Capacity in Inhabitant Equivalent (PE) of 25,000 , and to treat a pollutant load of around $476 \mathrm{~kg}$ of BOD5 / d. E.H (ONEP, 2012)

It has a total of 5 pools:

- Gauging structure (venturi)

- Screen

- Distribution chamber ${ }^{\circ} 1$

- Two anaerobic basins with a volume each of $2342 \mathrm{~m} 3$

- Distribution chamber $\mathrm{n}^{\circ} 2$

- Three optional basins with a volume each of $12,742 \mathrm{~m} 3$

- $300 \mathrm{ml}$ drainage structure for purified water towards Oued Moulouya

- A guardian lodge

- An operating building comprising a laboratory, a store and an office.

\subsection{Physico-chemical analysis}

Analyzes are performed monthly on 24 hour composite samples taken automatically every hour. Samples are taken at the entrance to the WWTP (raw water) and at the outlet of the station (treated water).

The measurements carried out are:

- On-site parameters, namely temperature, conductivity and $\mathrm{pH}$.

- The physico-chemical parameters (COD, DB05, MES, O2, PO43-, NO3-).

The $\mathrm{pH}$, conductivity and BOD5 measurements are performed respectively by a HANNA HI 8314 type $\mathrm{pH}$ meter, a WTW conductivity meter (cond 315i), an EUTCH oximeter (cyberscan DO300) and a HACH $2100 \mathrm{~N}$ turbidimeter.

For the COD and MES measurements, they are carried out respectively by the colorimetric method (ISO, 2002) and the gravimetric method (N.M, 1996) with a BAXTRANE type balance with a precision of $5 \mu \mathrm{g}$.

\section{RESULTS AND DISCUSSIONS}

The performances of the STEP were monitored during the period from November 2014 to October 2015.

\subsection{Temperature and $\mathrm{pH}$}

Figure 3 shows the variations in the $\mathrm{pH}$ and temperature of raw and purified water during the period from November 2014 to October 2015. It is important to remember that the $\mathrm{pH}$ gives an idea of the alkalinity of the medium which must be lying in the range of $6.5-8.5$ which represents the limit of direct release (Order, 2013). The $\mathrm{pH}$ of the raw wastewater entering the station varies between 6.98 and 8.17, these values are within the range of direct discharge limits which is between 6.5 and 8.5 (Order, 2013). The purification has led us to stable $\mathrm{pH}$ values between 7.19 and 8.32, with an average value of around 7.65 indicating a low alkalinity of the water, this average is in the range of Moroccan standards (NM, 2002). Since nitrogen denitrification in wastewater slows down with decreasing temperature (Adouani, 2015).

The temperature of raw wastewater in the city of Outat El Haj is between $13.1^{\circ} \mathrm{C}$ and $28.5^{\circ} \mathrm{C}$ with an average of $21.6^{\circ} \mathrm{C}$, those of the treated wastewater at the outlet are between 10,7 and 28.1 with an average of $20^{\circ} \mathrm{C}$. These recorded temperatures are included in the range of limit values for direct discharge into the receiving environment (Order, 2013) and in the range of Moroccan water quality standards for irrigation (NM, 2002).

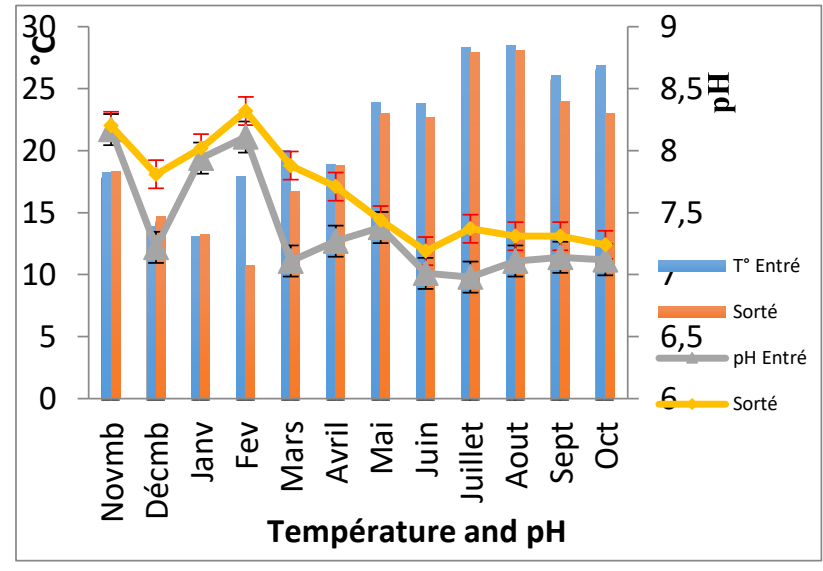

Figure 2. Variation in $\mathrm{T}$ and $\mathrm{pH}$ values at the entrance and exit of the WWTP

\subsection{Turbidity and Electrical Conductivity}

Turbidity measures the content of water in suspended particles, minerals or microorganisms (WHO, 2007) [10]. The latter increases from upstream to downstream from 67 to $176.8 \mathrm{NTU}$ (Figure 3), thus exceeding the Moroccan standards which are set at 5 NTU (N.M, 2013).

Conductivity reflects the degree of global mineralization, it tells us about the salinity rate. The conductivity values recorded at the level of raw wastewater in the city of Outat El Haj vary between $1916 \mu \mathrm{s} / \mathrm{cm}$ and $4110 \mu \mathrm{s} / \mathrm{cm}$ with an average of $2626 \mu \mathrm{s} / \mathrm{cm}$ (Figure 3), the purified wastewater presents values conductivity between $1882 \mu \mathrm{s} / \mathrm{cm}$ and 3100 with an average of $2241.6 \mu \mathrm{s} /$ $\mathrm{cm}$. This average conductivity remains close to the limit values for direct discharges, and below the maximum value $3000 \mu \mathrm{s} / \mathrm{cm}$ of water intended for irrigation (N.M, 2013).

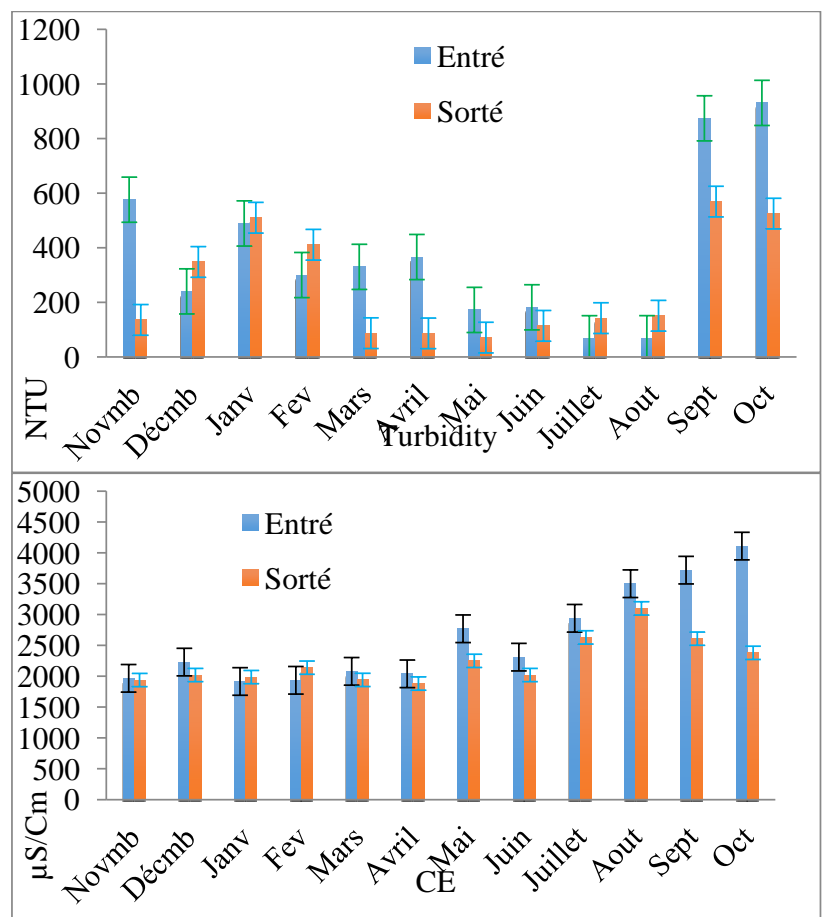

Figure 3. Change in the values of the CE and NTU at the entrance and exit of the WWTP 


\subsection{Dissolved Oxygen and Salinity}

The concentration of dissolved oxygen at the entry and exit of the station is almost zero, with an average value of $0.23 \mathrm{mg} / 1$ due to the high organic load in the raw wastewater, despite the degradation of this pollution during purification led us to almost zero concentrations, with an average value of around $0.25 \mathrm{mg} / 1$ at the outlet of the station. This average value is lower than that found in Marrakech (Bouarab et al, 1994), and also lower than that found by Naji (Naji, 1989) and that found in Errachidia by Chaouki (Chaouki et El Watik, 2014). Comparison of the dissolved oxygen values in the wastewater, analyzed with the surface water quality grid, (CNS, 1994) allows us to deduce that this wastewater is of very poor quality.

In wastewater treatment networks, its complete disappearance is generally accompanied by the appearance of $\mathrm{H}_{2} \mathrm{~S}$ in the air, resulting from the reduction of sulfur compounds present in the effluents, and created by the phenomena of acid attack of the concrete for pipelines (Thomas, 1995). This makes the wastewater of the town of Outat El Haj under saturated with oxygen, which accentuates anaerobic fermentation and the release of bad odors. This makes the wastewater of the town of Outat El Haj under saturated with oxygen which accentuates anaerobic fermentation and the release of bad odors.

In general, salinity follows the same trends as electrical conductivity, the results obtained show that the values at the entrance to the station oscillate between $1 \mathrm{mg} / 1$ and $1.8 \mathrm{mg} / 1$ with an average of $1.17 \mathrm{mg} / 1$, those at the outlet oscillate between $0.8 \mathrm{mg} / 1$ and 1.2 with an average of $1.04 \mathrm{mg} / 1$.

Comparing these values with the standard discharge grid shows that the raw wastewater in the city of Outat El Haj is of poor quality.

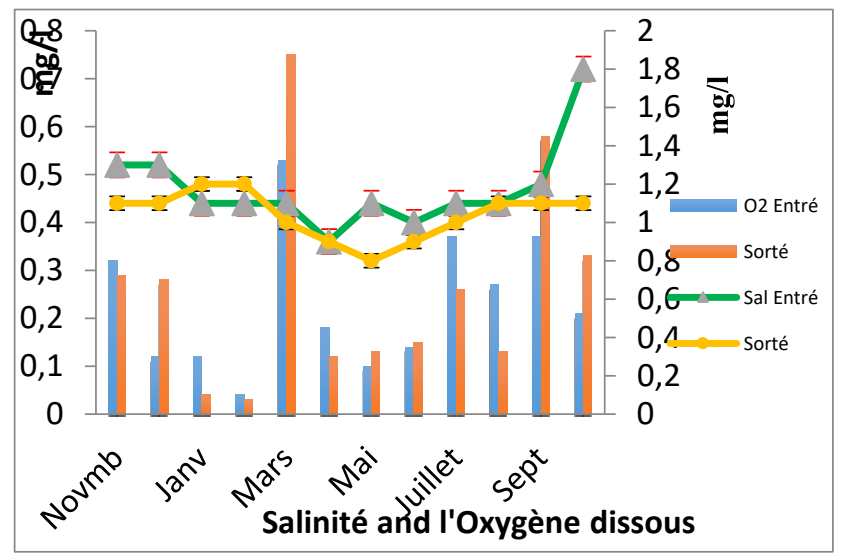

Figure 4. Variation in dissolved oxygen and salinity values

\subsection{Chemical oxygen demand (COD)}

The COD makes it possible to assess the concentration of organic or mineral matter, dissolved or suspended in water, through the quantity of oxygen necessary for their total chemical oxidation. The COD values at the inlet vary between $1274 \mathrm{mg} / 1$ and 1960 $\mathrm{mg} / 1$, those at the outlet vary between $130 \mathrm{mg} / 1$ and $1094 \mathrm{mg} /$ 1 with an average of $665.9 \mathrm{mg} / 1$. These output values show us the average reduction of the WWTP is-à-this carbon pollution, this reduction reaches $59 \%$. On the other hand, these recorded values exceed the Moroccan limit value for indirect discharge by $100 \mathrm{mg}$ / L (Ministry of the Environment of Morocco, 2013).

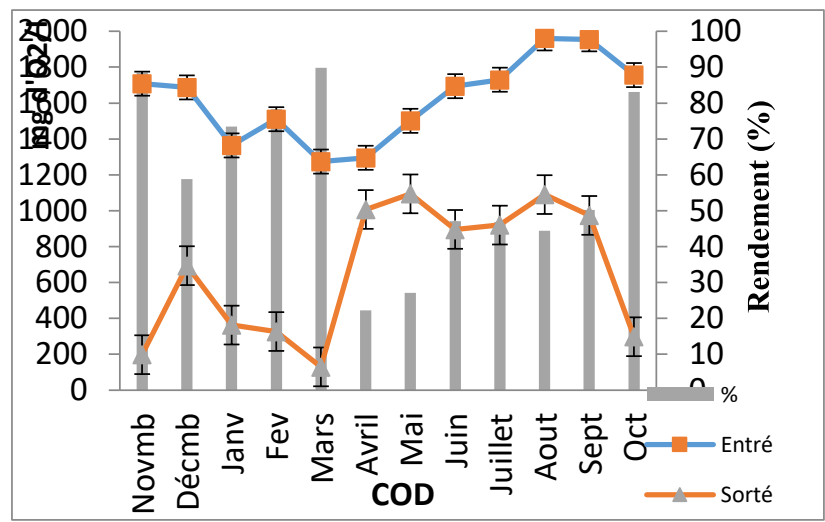

Figure 5. Change in COD values at the entry and exit of the WWTP

\subsection{Biological oxygen demand (BOD 5$)$}

The $\mathrm{BOD}_{5}$ concentrations at the inlet vary between $650 \mathrm{mg} / 1$ and $1120 \mathrm{mg} / 1$, those at the outlet vary between $60 \mathrm{mg} / 1$ and 550 $\mathrm{mg} / 1$ with an average of around $319 \mathrm{mg} / \mathrm{L}$ it exceeds of $20 \mathrm{mg}$ / 1 the Moroccan limit value for indirect discharge (Ministry of the Environment of Morocco, 2013). This indicator makes it possible to assess the Biochemical Oxygen Demand for the natural destruction of organic matter present in water (Rodier, 2009). The BOD5 removal efficiency ranges from $23 \%$ in April to $95 \%$ in January, with an annual efficiency of $61.5 \%$.

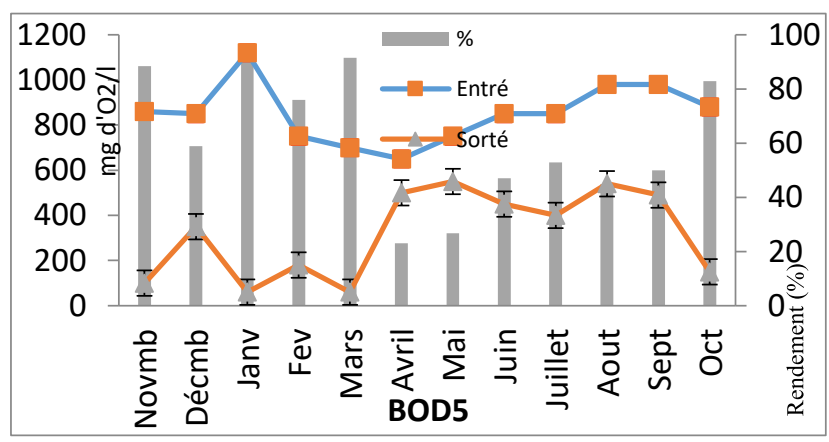

Figure 6. Change in $\mathrm{BOD}_{5}$ values at the entrance and exit of the WWTP

\subsection{Organic materials}

Figure 7 shows the evolution of OM values at the entrance and exit of the Outat El Haj WWTP. The results obtained at the entrance to the station show that the values vary between a maximum of $1306 \mathrm{mg} / 1$ and a minimum of $865 \mathrm{mg} / 1$ with an average of $1107 \mathrm{mg} / 1$, that of the exit varies between $731 \mathrm{mg} / 1$ and $83 \mathrm{mg} / 1$ with an average of $434 \mathrm{mg} / 1$. Recorded values it exceeds the Moroccan limit value for indirect discharge by $10 \mathrm{mg}$ / L (Ministry of the Environment of Morocco, 2013). The OM removal efficiency ranges from $23 \%$ in April to $90.6 \%$ in March, with an annual efficiency of $60.5 \%$. 


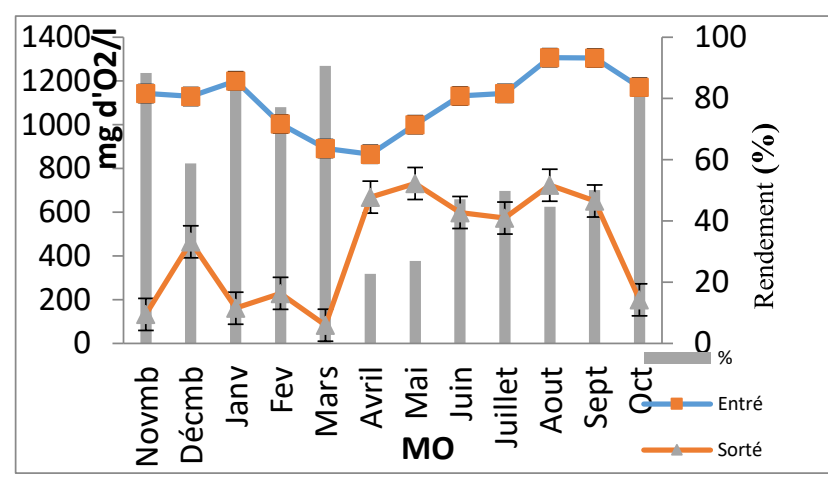

Figure 7. Variation of OM values at the entrance and exit of the WWTP

\subsection{Suspended Materials}

TSS represents the solids (small particles of solid pollutants) contained in wastewater (Hamid, 2014). They can be retained by filtration or centrifugation (Rodier, 2009). Its annual average concentration in the raw effluent is of the order of $949 \mathrm{mg} / \mathrm{L}$ which is greater than $600 \mathrm{mg} / \mathrm{L}$ considered as the Moroccan threshold value for indirect discharge (Ministry of the Environment of Morocco, 2013).

The mean value of the TSS at the outlet of the WWTP is of the order of $657.7 \mathrm{mg} / \mathrm{L}$. Its minimum value is $82 \mathrm{mg} / \mathrm{L}$ recorded during the month of April and its maximum value is $1016 \mathrm{mg} / \mathrm{L}$ recorded during the month of January.

The removal efficiency fluctuates between $9.1 \%$ in May and $65.6 \%$ in October. The highest values of the three parameters were recorded during the winter period, this is explained by the heavy precipitation during this period which leads to the transport of suspended matter associated with organic molecules to the station (N'diaye, 2013; Marechal , 2000).

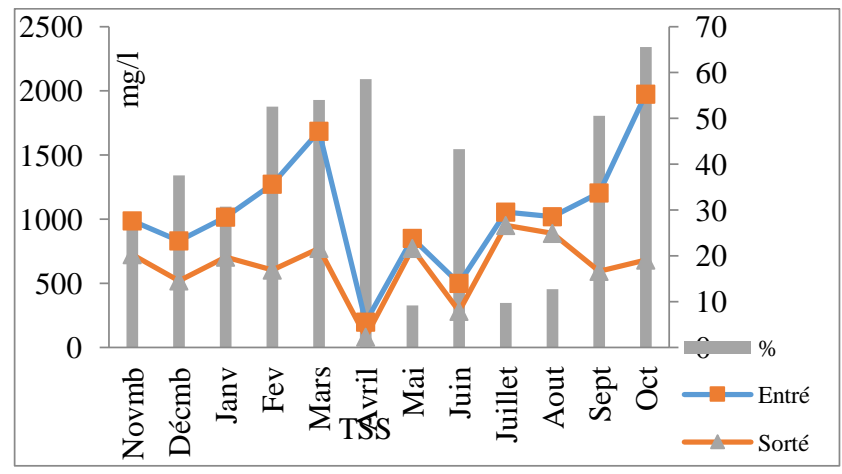

Figure 8. Variation of TSS values at the entrance and exit of the WWTP

\subsection{Nitrates and Orthophosphates}

The reduction of phosphorus and nitrogen is a necessity to reduce the phenomena of eutrophication (Water, Environments, GMOs, 2014).

Figure 12 shows the evolution of the content of Nitrates and Orthophosphates in raw and purified wastewater. The minimum monthly average $(3.5 \mathrm{mg} \mathrm{N} / \mathrm{L})$ is obtained in June and the maximum (19.7 mg N/L) is obtained in April.
Nitrates are the final stage in the oxidation of nitrogen, and represent the highest oxidized form of nitrogen found in water. Their concentrations in natural waters are between 1 and $10 \mathrm{mg} /$ L. However, their contents in untreated wastewater are low (UNEP).

The results of nitrate analyzes show a significant increase after treatment. The concentration of wastewater from the WWTP has gone from $26 \mathrm{mg} / 1$ as an average value at the inlet of $39.6 \mathrm{mg} / 1$ average value at the outlet, remaining below the value admissible by Moroccan standards (50 mg / 1) (NM, 2013). As a result, the waters studied are not subject to a risk of pollution by nitrates.

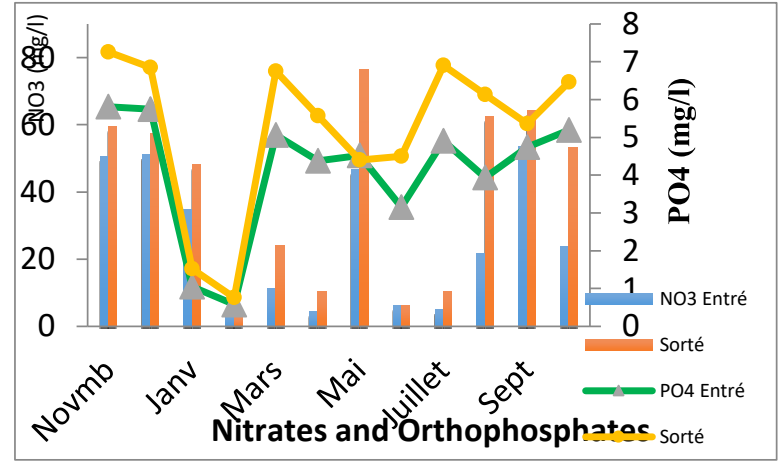

Figure 9. Variation of the values of Nitrates and Orthophosphates

\section{CONCLUSION}

The performance of the Outat El Haj WWTP was monitored in order to determine the degree of physical-chemical pollution of the raw water on the one hand and to assess the effectiveness of the treatment by natural leaning. 'somewhere else. The station receives significant organic and inorganic pollution, which remains below the nominal capacity of the WWTP. The $\mathrm{pH}$ values of temperature and conductivity remain within the indirect release ranges and do not interfere with biological treatment. The monitoring of the WWTP's performance made it possible to conclude:

He purification yields of the natural lagoon-type WWTP reached the average values of $61.4 \%, 59.1 \%, 60.5 \%$ and $37.6 \%$ respectively for BOD5, COD, OM and TSS.

These values show an average purification performance of the station, due to the size of the basins and adaptation systems for microorganisms that biodegrade organic matter, the quality of the effluents produced makes them unsuitable for reuse for irrigation of the land of agriculture [23].

Obligation to renew and rehabilitate the WWTP, which consist in converting the station from a natural lagoon to an aerated lagoon to increase the purification efficiency of the WWTP, and therefore the possibility of reusing the treated water.

\section{REFERENCES}

JACQUET V. Déminéralisation par électrodialyse en présence d'un complexant application au lactosérum. Thèse de doctorat d'université. Toulouse : Institut National Polytechnique 1999, $122 \mathrm{p}$.

Mandi, L. and Ouazzani, N. Water and Wastewater Management in Morocco Biotechnologies Application, 2013. 
Makhokh, M. and Bourziza, Ms. Country Report for the Expert Consultation on Wastewater Management-MOROCCO-SEEEONEP.22-24 May 2011, Dubai, UAE, 2011.

ISO 15705 : 2002 - Qualité de l'eau - Détermination de l'indice de demande chimique en oxygène (ST-DCO) - Méthode à petite échelle en tube fermé.

Norme Marocaine, Détermination des matières en suspension, NM 03.7.052 (1996);

(Ministry of the Environment of Morocco, 2013). Arrêté conjoint du ministre de l'intérieur, du ministre de l'énergie, des mines, de l'eau et de l'environnement, du ministre de l'industrie, du commerce et des nouvelles technologies et du ministre de l'artisanat ${ }^{\circ}$ 2942-13 du 1er hijja 1434 fixant les valeurs limites générales de rejet dans les eaux superficielles ou souterraines. B.O. $\mathrm{n}^{\circ} 6202$ du 7 novembre 2013.

Bulletin officiel $n^{\circ} 5062$ du 30 ramadan 1423 (5 décembre 2002) portant fixation des normes de qualité des eaux destinées à l'irrigation.

Adouani, N.Limousy, L. Lendormi, T and Sire, O, $\mathrm{N}_{2} \mathrm{O}$ and NO emissions during wastewater denitrification step: Influence of temperature on the biological process, January 2015.

(Ministry of the Environment of Morocco, 2002)

WHO (2007). The world health report, Summary of orientation. <URL: www.who.int/whr/2007/fr/

UNEP/MAP/MEDPOL. Guidelines on environmental inspection systems for mediterranean region. MAP technical reports series $2004, \mathrm{~N}^{\circ} 149$.

L. Bouarab, N. Ourzzani, B. Oudra, J. Darley, Picot B. et J. Bontoux, "Evolution des formes d'azote dans la station expérimentale de lagunage naturel de Marrakech, " Actes Quatrième Conférence Internationale des Limnologues d'Expression Française. Marrakech, Tome II (25-28 Avril 1994), 1994.

S. Naji, Institut sucrier d'étude de recherche et de formation les eaux du circuit hydrique de SUBM. Rapport interne, 1989.

H. Chaouki et L. El watik, "étude des performances épuratoires de la technique du lagunage aérée de la station d'épuration de la ville d'Errachidia- Maroc," ScienceLib Editions Mersenne : Volume 6, $\mathrm{N}^{\circ} 140101$ ISSN 2111-4706, 2014.

Comité Normes et Standards, (CNS), Ministère de l'environnement du Maroc. Rabat, 1994.

O. Thomas, Métrologie des eaux résiduaires, Ed. Cebedoc / Tec. et Doc. 11, Liège -75384, Paris, 1995.

Hamid C., Elwatik L., Ramchoun Y., Fath-allah R, Ayyach A., Fathallah Z., Elmidaoui A. et Hbaiz, E, Étude des performances épuratoires de la technique du lagunage aéré appliquée à la station d'épuration de la ville d'Errachidia- Maroc, 2014.

RODIER J. (2009). L'analyse de l'eau naturelle, eaux résiduaires, eau de mer, 9 Edition Dunod, Paris, 1579p.
N'diaye A D., Thiam O., OuldKankou M. et IbnoNamr K., Turbidité et matières en suspension dans l'eau : application a l'évaluation des métauxcontenus dans l'eau de la rive droite du fleuve Sénégal. juin 2013.

Marechal A., Relations Entre Caractéristiques de la Pollution Particulaire et Paramètres Optiques dans les Eaux Résiduaires Urbaines, 2000.

Bulletin Officiel n ${ }^{\circ} 5448$ du Jeudi 17 Août 2006 portant fixation des valeurs limites spécifiques de rejet domestique ;

Eau, Environnements, OGM, Coordination Rurale : Nitrates, phosphates et eutrophisation : le débat est ouvert !, 2014. 